\title{
ФОРМУВАННЯ САМООСВІТНЬОЇ КОМПЕТЕНЦІЇ МАЙБУТНІХ ФАРМАЦЕВТІВ У СВІТЛІ ОНОВЛЕННЯ ЗМІСТУ ВИЩОЇ ОСВІТИ
}

\author{
B. M. Palasiuk \\ I. Horbachevsky Ternopil National Medical University
FORMATION OF SELF-EDUCATIONAL COMPETENCE OF FUTURE PHARMACISTS IN THE LIGHT OF UPDATING THE CONTENT OF HIGHER EDUCATION

\begin{abstract}
Анотація. Вища освіта є одним із визначальних чинників, що впливають на професійне становлення людини. Формування самоосвітньої компетентності студентів сприятиме підвищенню якості підготовки майбутніх фахівців у контексті глобалізації освіти і підвищення їх конкурентоспроможності на ринку праці. Однією з форм самоосвітньої діяльності є самостійна робота. Біофізику студенти-фармацевти медичних закладів вищої освіти IV рівня акредитації вивчають на першому році навчання. Основна частина навчального навантаження для студентів фармацевтичного факультету заочної форми навчання припадає на самостійну роботу. У загальній системі організації самостійної роботи студентів заочної форми навчання особливе місце займає контрольна робота з навчальної дисципліни. Перед виконанням контрольної роботи студенти заочної форми навчання самостійно вивчають теоретичний матеріал, розміщений на сайті університету. Обсяг інформації, який міститься в ньому, оптимізований та адаптований для студентів заочної форми навчання. Під час вивчення дисципліни майбутні провізори повинні опанувати базові знання для блоку дисциплін, що забезпечують професійно-практичну підготовку. Виконання контрольної роботи вимагає формування вмінь самостійно працювати з навчальною літературою. Для підвищення ефективності самостійної роботи і для допомоги студентам-заочникам у виконанні контрольної роботи розроблено варіанти контрольних завдань із біофізики. Завдання контрольної роботи побудовані так, що дозволяють не тільки об’єктивно перевірити рівень знань студентів, а й активізувати їх пізнавальну активність, забезпечити повторення раніше засвоєних знань, застосувати сформовані уміння і навички для активного сприйняття нового матеріалу.
\end{abstract}

Ключові слова: біологічна фізика; самоосвітня компетенція; самостійна робота; заочна форма навчання; контрольна робота.

Abstract. Higher education is one of the determinative factors that have an influence on a person's professional development. The formation of students' self-educational competence will promote the quality of future professionals' training in the context of educational globalization and increase their competitiveness in the labour market. An independent work is one of the forms of self-educational activity. Pharmaceutical students of medical institutions of higher education of the $\mathrm{IV}^{\text {th }}$ level of accreditation learn biophysics during the first year of study. An independent work is the main part of the studying load for the students of Faculty of Pharmacy of part-time training. The control work in academic discipline plays an important role in the general system of organization of students' independent work of the part-time training. To do the control work, the part-time training students study independently the theoretical material, located on the university website. The amount of information in discipline located on the university website is optimized and adapted for part-time training students. Future pharmacists must acquire basic knowledge for the block of disciplines that provide professional and practical training during the discipline learning. The formation of skills to work independently with educational literature is necessary to do the control work. To increase the efficiency of independent work and to help part-time training students in the doing the control work, variants of control tasks in biophysics have been developed. The tasks of the control work are organized so that not only allow objectively check the level of students' knowledge, but also to intensify their cognitive activity, to ensure the review of previously acquired knowledge, to apply the skills and abilities for active perception of new material.

Key words: biological physics; self-educational competence; independent work; part-time training; control work.

Вступ. Вища освіта $є$ одним із визначальних чинників, що впливають на професійне становлення людини. Від якості здобутої освіти безпосередньо (c) Б. М. Паласюк залежить успішність окремої людини і в цілому позитивний розвиток усього суспільства. У зв'язку 3 цим провідною метою вищої освіти сучасного спеціаліста є формування професійного потенціалу, 
що забезпечуватиме йому вирішення на належному рівні як повсякденних проблем у професійній діяльності, так і професійне самовдосконалення, вміння вирішувати нові професійні завдання, які, безумовно, виникатимуть протягом здійснення професійної кар’єри.

Реалії сучасного світу диктують необхідність створення нових підходів до забезпечення професійного становлення майбутнього фахівця, які дозволили б студентам у процесі професійної підготовки сформувати особистісні якості та компетентності, необхідні для адаптації до постійно змінного соціуму. Таке соціальне замовлення суспільства вносить зміни в систему професійної освіти. Практично змінюється філософія навчання. На зміну біхевіористичним, когнітивістським, конструктивістським уявленням про суть передачі інформації прийшли інтерактивність та співробітництво у взаємодії між викладачем та тими, хто навчається, а також індивідуальна робота над джерелами знань. Відповідно суттєво реформуються дидактичні прийоми, принципи формування мотивації.

Удосконаленню системи вищої освіти сприятиме кардинальне оновлення її змісту, який ще значно відстає від глобальних тенденцій розвитку суспільства, потреб розвитку особистості в умовах демократизації суспільства. Спроби модернізувати змістовий бік шляхом уведення у навчальні плани певних навчальних дисциплін або збільшення обсягів навчального матеріалу спричиняє перевантаження студентів, що, у свою чергу, позбавляє їх можливості поглиблювати свої знання самостійно, набувати навичок самоосвіти.

Водночас досвід показує, що студенти медичних закладів вищої освіти ще не готові і не вміють ефективно організувати процес самоосвітньої діяльності, а її інтенсифікація базується в основному на сучасних методах і технологіях навчання.

Мета статті - проаналізувати особливості формування самоосвітньої компетентності студентів фармацевтичного факультету заочної форми навчання медичних закладів вищої освіти.

Теоретична частина. У сучасному інформаційному суспільстві відбувається швидке накопичення й постійне оновлення інформації, що зумовлює динамічне зростання вимог до професійних якостей фахівців. За таких умов неможливо навчити людину на все життя, необхідно закласти в ній інтерес і прагнення до оновлення знань, навчити ії вчитися.
На сучасному етапі важливим $є$ не стільки обсяг інформації, скільки вміння її знаходити, розуміти, вибирати, структурувати, використовувати у своїй діяльності. Актуалізується проблема формування самоосвітньої компетентності студентів, вирішення якої сприятиме підвищенню якості підготовки майбутніх фахівців у контексті глобалізації освіти і підвищення їх конкурентоспроможності на ринку праці [4].

У сучасній психолого-педагогічній літературі знаходимо тлумачення поняття «самоосвітня компетентність». Зокрема, I. Зимня поняття самоосвітньої компетентності трактує як здатність навчатися впродовж життя, основу неперервного навчання в контексті як особистого професійного, так і соціального життя [3].

Цілком слушне $\epsilon$, на нашу думку, твердження В. В. Атаманюка, що пріоритетом нині є навчання, орієнтоване на саморозвиток, самоосвіту і самореалізацію майбутнього фахівця [1]. Тому одним із завдань вищої освіти в сучасних умовах $€$ вироблення у майбутнього спеціаліста стійкого усвідомлення потреби у постійному самовдосконаленні всіма можливими методами та засобами.

Американські дослідники С. Меріам та Р. Кафелл (S. Merriam, R. Caffarella) трактують самоосвітню діяльність як форму навчання, у якій студенти несуть основну відповідальність за планування, виконання та оцінювання свого досвіду навчання [7]. У цьому руслі пропонуємо розглядати самоосвіту майбутніх провізорів як специфічний вид діяльності, який здійснюється особистістю на добровільних засадах з метою задоволення пізнавальних потреб або покращення власних особистісних властивостей і здібностей. Тільки ті знання, які студент здобув самостійно, завдяки власному досвіду, думці і дії, будуть насправді міцні. Саме тому вища школа поступово, але неухильно переходить від передачі інформації до керівництва навчально-пізнавальною діяльністю, формування у студентів навичок самостійної творчої роботи.

Однією з форм самоосвітньої діяльності є самостійна робота. Як складне педагогічне явище самостійна робота студентів - це особлива форма навчальної діяльності, головною метою якої є формування самостійності студентів, а формування їх умінь, знань і навичок здійснюється безпосередньо через зміст та методи всіх видів навчальних занять.

Дослідження М. Фреймана і С. Фреймана містять тлумачення поняття «самостійність» як особис- 
тісної риси студента, що виявляється у здатності визначати та модифікувати способи розв'язання навчальних завдань без активного контролю викладача [6]. Самостійність не є вродженою властивістю людини, світу в цілому, а, насамперед, умовою життевого успіху кожної окремо взятої особистості.

Відмінність самостійної роботи від самоосвіти полягає в тому, що самостійна робота в основному породжується і керується ззовні, тоді як самоосвітня діяльність - внутрішніми мотивами, які, на думку Н. Воропай, виходять за межі навчальних [2]. Інколи самостійна робота і самоосвітня діяльність настільки тісно переплітаються, що їх складно розмежувати.

Самостійна робота є основним засобом засвоєння студентом навчального матеріалу в час, вільний від обов'язкових навчальних занять. Аналіз нормативних документів дав змогу з'ясувати, що навчальний час, відведений для самостійної роботи студента, регламентується навчальним планом і повинен становити не менше 1/3 та не більше 2/3 загального обсягу навчального часу (тобто 50-60 \% навчального часу), відведеного для вивчення конкретної навчальної дисципліни.

Співвідношення обсягів аудиторних занять і самостійної роботи студентів визначається з урахуванням специфіки та змісту конкретної навчальної дисципліни, її місця, значення і дидактичної мети в реалізації освітньо-професійної програми, а також питомої ваги в навчальному процесі практичних, семінарських і лабораторних занять [7].

Самостійна робота $є$ однією із важливих складових сучасної професійної підготовки висококваліфікованих та конкурентоздатних фахівців 3 фармації, адже у своїй майбутній діяльності для вирішення різних проблемних ситуацій у своій професійній діяльності провізор повинен самостійно орієнтуватись у великих об’ємах нової інформації.

Біологічну фізику студенти-фармацевти медичних закладів вищої освіти IV рівня акредитації вивчають на першому році навчання. Ця послідовність методично виправдана, оскільки фундаментальні дисципліни складають ту основу, на якій базуються знання та навички спеціаліста-провізора, формуються його світогляд та логіка мислення.

Процес навчання базується на попередньо вивчених студентами в середній загальноосвітній школі таких предметів, як фізика, хімія, математика. Вивчення біологічної фізики забезпечує високий рівень загальної фізичної та хімічної підготовки, закладає студентам фундамент для подальшого засвоєння ними знань із профільних дисциплін (фармацевтичної хімії, аналітичної хімії, токсикологічної хімії тощо).

У курсі біофізики студенти опановують теорію і практику фізичного аналізу фармацевтичної та медико-біологічної інформації. Студенти вчаться аналізувати і розв'язувати задачі фармацевтичного та медико-біологічного змісту, самостійно використовувати відповідну фізичну літературу та обчислювальну техніку, користуватися пакетами прикладних програм.

Фундаментальна і професійна спрямованість навчання біологічної фізики полягає у поєднанні глибоких фундаментальних знань біофізики з їх професійною спрямованістю, оскільки всі сучасні технології та методи дослідження у фармації базуються на фундаментальних законах біофізики і їх використанні. Вивчення біологічної фізики формує у студентів цілісне уявлення про різні фізичні константи, за якими оцінюється якість субстанцій лікарських речовин; теоретичні засади та практичне застосування фармакопейних методів аналізу, що застосовуються для контролю якості субстанцій лікарських речовин та готових лікарських засобів; забезпечує фундаментальну підготовку та набуття практичних навичок для майбутньої професійної діяльності провізора.

Особливої уваги потребує засвоєння біологічної фізики студентами заочної форми навчання, адже обсяг часу, відведений на аудиторні заняття для таких студентів, значно менший порівняно із денною формою навчання (лекції - 8 год, практичні заняття - 18 год, самостійна робота студентів - 109 год), тому основна частина навчального навантаження для студентів фармацевтичного факультету заочної форми навчання припадає на самостійну роботу.

Мета самостійної роботи студентів заочної форми навчання поляга $є$ і у формуванні самостійності як риси особистості, і у засвоєнні знань, умінь, навичок. У загальній системі організації самостійної роботи студентів заочної форми навчання особливе місце займає контрольна робота з навчальної дисципліни. Контрольна робота - це основна форма роботи студента над засвоєнням навчального матеріалу у міжсесійний період. Контрольні роботи виконують усі студенти заочної форми навчання самостійно. Дидактичною метою контрольної роботи $€$ не лише перевірка рівня засвоєння навчального матеріалу, але й закріплення отриманих теоретичних знань і набутих практичних навичок. Адже для успішного виконання контрольної роботи потрібно 
опрацювати і засвоїти програмовий матеріал навчального курсу.

Програма з біологічної фізики розділена на три змістових блоки: 1) функціонування біомеханічного, електромагнітного та оптичного медичного обладнання; 2) фізичні методи аналізу, які грунтуються на вимірюванні фізичних властивостей (параметрів) системи без проведення хімічних реакцій; 3) фізико-хімічні методи, які грунтуються на вимірюванні фізичних або фізико-хімічних властивостей (параметрів) системи при проведенні хімічної реакції з об’єктом аналізу.

Перед виконанням контрольної роботи студенти заочної форми навчання самостійно вивчають теоретичний матеріал, розміщений на сайті університету. Обсяг інформації, який міститься в ньому, оптимізований та адаптований для студентів заочної форми навчання. Під час вивчення дисципліни майбутні провізори повинні поглибити і вдосконалити знання, уміння і практичне розуміння біофізичних процесів у живому організмі; фізичних методів діагностики захворювань і дослідження біологічних систем; впливу фізичних факторів на організм людини при її лікуванні; фізичних властивостей матеріалів, які використовуються в медицині та фармації; фізичних властивостей і характеристик оточуючого середовища, тобто опанувати базові знання для блоку дисциплін, що забезпечують професійно-практичну підготовку. Якщо завдання для самостійної роботи дають відповідь на запитання студента «Де це нам знадобиться?», то тим самим створюються необхідні психологічні умови для іiї здійснення. Окрім того, виконання контрольної роботи вимагає формування вмінь самостійно працювати з навчальною літературою.

Для підвищення ефективності самостійної роботи і для допомоги студентам-заочникам у виконанні контрольної роботи на кафедрі медичної фізики діагностичного та лікувального обладнання Тернопільського національного медичного університету імені І. Я. Горбачевського розроблено варіанти контрольних завдань з біофізики. Кожен студент отримує варіант контрольної роботи, який складається 314 задач. Всі варіанти містять індивідуальний набір задач, що максимально знижує можливість механічного списування студентами завдань.

Зміст контрольних робіт охоплює всі розділи курсу: 1. Біомеханіка; 2. Біореологія та гемодинаміка; 3. Молекулярно-кінетична теорія газів. Явища переносу. Термодинаміка біологічних процесів; 4. Елементи біофізики мембранних процесів в клітинах; 5. Електродинаміка медико-біологічних систем; 6. Оптичні методи дослідження біологічних систем; 7. Основи квантової біофізики. Рентгенівське та радіоактивне випромінювання. Теплове випромінювання тіл.

Професійно орієнтована задача передбачає високий рівень самостійності дій студента при її вирішенні. А самостійність забезпечується переліком вихідних даних і умовами задачі. Для усунення труднощів при виконанні самостійної роботи перед задачами до кожного розділу наводимо приклади розв’язаних типових задач.

Завдання побудовані так, що дозволяють не тільки максимально об’єктивно перевірити рівень знань студентів, а й активізувати їх пізнавальну активність, забезпечити повторення раніше засвоєних знань, застосувати сформовані уміння і навички для активного сприйняття нового матеріалу.

Підвищення значення самостійної роботи студентів потребує грунтовної переоцінки засад організації навчального процесу, який, на наше переконання, повинен будуватися так, щоб посилювати бажання здобувати нові знання, формувати орієнтованість до саморозвитку та вміння творчо застосовувати отримані знання в процесі вирішення навчальних завдань, i, врешті-решт, сприяти підвищенню конкурентоспроможності випускників медичного коледжу на ринку праці та освітніх послуг.

Висновки та перспективи подальших досліджень. Викладене дозволяє зробити висновок, що у процесі фахової підготовки майбутніх провізорів самостійна робота є основним засобом засвоєння студентом навчального матеріалу у час, вільний від обов'язкових навчальних занять. Основним видом самостійної роботи студентів заочної форми навчання у медичному закладі вищої освіти є контрольні роботи. Зміст запропонованих контрольних робіт охоплює всі розділи курсу «Біологічна фізика», а їх завдання дозволяють оцінити рівень базових знань для блоку дисциплін, що забезпечують професійно-практичну підготовку.

Керуючи самостійною роботою, викладач мотивує, планує, організовує позааудиторну самостійну роботу студента за допомогою відповідного методичного забезпечення. Важливу роль для активізації творчої пізнавальної діяльності студентів відіграють завдання дослідного, пошукового характеру. Проблеми розробки таких завдань і шляхи активізації самоосвітньої діяльності майбутніх фармацевтів будуть розглянуті нами у подальших дослідженнях. 


\section{Список літератури}

1. Атаманюк В. В. Проблема самостійної навчальнопізнавальної діяльності студентів у контексті розбудови вищої школи в Україні / В. В. Атаманюк, І. В. Шимкова // Сучасні інформаційні технології та інноваційні методики навчання у підготовці фахівців: методологія, теорія, досвід, проблеми : зб. наук. праць / редкол. : І. А. Зязюн (голова) та ін. - К. ; Вінниця : ТОВ фірма «Планер», 2010. - Вип. 24. - С. 211-218.

2. Воропай Н. А. Самостійна робота студентів як засіб індивідуалізації їхнього навчання / Н. А. Воропай // Вісник Прикарпатського університету. Педагогіка : зб. наук. праць. - Івано-Франківськ : Видавничо-дизайнерський відділ ЦІТ ПНУ ім. В. Стефаника, 2008. Вип. 24. - С. 52-57.

3. Зимняя И. А. Ключевые компетентности - новая парадигма результата образования / И. А. Зимняя // Высшее образование. - 2003. - № 5. - С. 34-42.

\section{References}

1. Atamanyuk, V.V., \& Shymkova, I.V. (2010). Problema samostijnoyi navchalno-piznavalnoyi diyalnosti studentiv u konteksti rozbudovy vyshchoyi shkoly v Ukrayini [The problem of students' independent educational and cognitive activity in the context of the development of higher education in Ukraine]. Suchasni informacijni texnologiyi ta innovacijni metodyky navchannya u pidgotovci fakhivciv : metodologiya, teoriya, dosvid, problemy : zb. nauk. prats. Modern information technologies and innovative teaching methods in specialists' training: methodology, theory, experience, problems: a collection of scientific papers. Kyiv : «Planer» [in Ukrainian].

2. Voropai, N.A. (2008). Samostiina robota studentiv yak zasib indyvidualizatsii yikhnoho navchannia [Independent work of students as a means of individualization of their studying]. Visnyk Prykarpatskoho universytetu. Pedahohika: zbirnyk naukovykh prats - Bulletin of Precarpathian University. Pedagogy: a collection of scientific works. Ivano-Frankivsk: Vydavnycho-dyzainerskyi viddil Tsit PNU im. V. Stefanyka [in Ukrainian].

3. Zimnyaya, I.A. (2003). Klyuchevyie kompetentnostinovaya paradigma rezultata obrazovaniya [Key competen-
4. Коростіль Л. А. Самоосвіта особистості як соціальне та педагогічне явище / Л. А. Коростіль // Педагогічні науки : зб. наук. праць. - Суми : Видавництво СумДПУ, 2009. - № 1. - С. 138-145.

5. Пелещишин А. М. Методи та алгоритми моделювання Web-систем / A. М. Пелещишин. - Режим доступу : http://disser. com.ua/contents/31604.html.

6. Фрейман С. Самостійність як важливий чинник організації педагогічного процесу / С. Фрейман, М. Фрейман // Наукові записки Тернопільського державного педагогічного університету. Серія «Педагогіка». - 2004. № 5. - C. 6-9.

7. Merriam S. B. Learning in Adulthood. A comprehensive guide / S. B. Merriam, R. S. Caffarella. - San Francisco : Jossey-Bass, 2011. - 229 p.

cies - a new paradigm of educational outcomes]. Vyissheie obrazovanie - Higher Education, 5, 34-42 [in Russian].

4. Korostil, L.A. (2009). Samoosvita osobystosti yak sotsialne ta pedahohichne yavyshche [Self-education of the individual as a social and pedagogical phenomenon]. Pedahohichni nauky: zb. nauk. prats. - Pedagogical sciences: Collection of Scientific works. Sumy: SumSPU Publishing House [in Ukrainian].

5. Peleshchyshyn, A.M. Metody ta alhorytmy modelyuvannya Web-system [Methods and algorithms for modeling Web-systems]. Retrieved from: http://disser. com. ua/contents/31604.html [in Ukrainian].

6. Freyman, S., \& Freyman, M. (2004). Samostiynist yak vazhlyvyy chynnyk orhanizatsiyi pedahohichnoho protsesu [Independence as an important factor in the organization of the pedagogical process]. Naukovi zapysky Ternopilskoho derzhavnoho pedahohichnoho universytetu. Seriya «Pedahohika»-Scientific notes of Ternopil State Pedagogical University. Series "Pedagogy”, 5, 6-9 [in Ukrainian].

7. Merriam, S.B., \& Caffarella, R.S. (2011). Learning in adulthood. A comprehensive guide. San Francisco: JosseyBass. 